\title{
Activation Energy, Half-Life and Yield of the Hydrolysis Reaction of Sucrose Catalyzed by the Enzyme Invertase Produced by Yeast Saccharomyces cerevisiae
}

\author{
Erich Potrich $^{1^{*}}$ and Larissa Souza Amaral ${ }^{2}$ \\ ${ }^{1}$ Department of Chemical Engineering PPGEQ, Federal University of São Carlos - UFSCar. \\ São Carlos - SP, 13566-590, Brazil \\ ${ }^{2}$ Program Interunits in Bioengineering EESC/FMRP/IQSC, University of São Paulo - USP. \\ São Carlos - SP, 13566-590, Brazil \\ *Corresponding author
}

\section{A B S T R A C T}

\section{Keywords}

Enzyme invertase, Sucrose hydrolysis, DNS method,

Activation energy, Half-life, Yield

Article Info

Accepted:

10 January 2018

Available Online:

10 February 2018
The enzyme invertase is produced by Saccharomyces cerevisiae. It hydrolyzes sucrose into glucose and fructose, having a great utility industrially. With this it is necessary to know its main characteristics to be able to know how to optimize it. In this research the enzyme invertase was worked in two types of reactors very common in the industrial area, the batch reactor and the fixed bed reactor. In the experiments described here, the type of reaction involved in hydrolysis, whether exothermic or endothermic, and what is its activation energy was determined. In the characterization of the enzyme the half-life and its maximum yield were determined. The DNS methodology was applied and a spectrophotometer of the FEMTO brand was used. The results obtained here show that the hydrolysis of saccharose is an exothermic reaction with activation energy of $25.07 \mathrm{~kJ}$. The invertase enzyme used herein has a half-life of 65.39 min and a maximum yield of $47.02 \%$. All adjusted curves had a $\mathrm{R}^{2}$ value above 0.91 , proving the reliability of the obtained results.

\section{Introduction}

Some microorganisms may be capable of producing various enzymes of industrial interest. Yeast Saccharomyces cerevisiae is an example of such microorganisms. It produces the enzyme invertase which is capable of hydrolyzing sucrose to produce the invert sugar, which is an equimolar mixture of glucose and fructose (Margetić and Vujčić, 2017). As fructose is about 25 to $40 \%$ sweeter than sucrose, and does not crystallize so easily by improving the texture of sweets and ice creams, sucrose hydrolysis is widely used in the food industry (Zamora et al., 1997). The enzymatic reaction has advantages over traditional methods. In comparison to acid hydrolysis with sulfuric acid, the enzymatic hydrolysis presents a lower energy consumption, besides the product obtained is of better quality (Baraldi et al., 2016).

Sucrose $\left(\mathrm{C}_{12} \mathrm{H}_{22} \mathrm{O}_{11}\right)+$ Water $\left(\mathrm{H}_{2} \mathrm{O}\right) \rightarrow$ Glucose $\left(\mathrm{C}_{6} \mathrm{H}_{12} \mathrm{O}_{6}\right)+$ Fructose $\left(\mathrm{C}_{6} \mathrm{H}_{12} \mathrm{O}_{6}\right)$ 
$342.30 \mathrm{~g} / \mathrm{mol}+18.02 \mathrm{~g} / \mathrm{mol} \rightarrow 180.16 \mathrm{~g} / \mathrm{mol}$ $+180.16 \mathrm{~g} / \mathrm{mol}$

Enzymes have advantages over chemical catalysts because of high substrate specificity and low by-product formation. However the enzymes present high sensitivity to the operating conditions of the industry, mainly in the matter of temperature (Homaei et al., 2013). Therefore a study of the hydrolysis reaction of sucrose and the enzyme invertase is necessary.

Knowing whether the reaction is exothermic or endothermic is extremely important. The advantage of the reaction being exothermic is that in addition to not needing to provide much energy for the reaction to occur, the reaction occurs at lower temperatures and thus there is no risk of denaturing the enzyme due to temperature.

However, if the reaction is endothermic, in addition to increased energy expenditure, it must have an efficient temperature control to maintain the reaction yield at a suitable value without denaturing the enzyme (Atkins, 2006).

Activation energy is the minimum energy that the reagents need to initiate the chemical reaction. The greater the value of this energy, the more difficult and the slower is the reaction (Cantu et al., 2014). While knowing whether the reaction is exothermic or endothermic is qualitative information, the activation energy is quantitative information.

Knowing the half-life of the enzyme is of extreme importance to know how much the incubation time influences the drop in the amount of enzyme available for the reaction (Yamane et al., 1987). In the case of the industry operating with fixed bed reactors because they are faster than batch reactors, knowing how much the reaction yield is influenced by the flow rate of the reactor helps to have a greater control in the reaction and thus to have the best possible yield.

The objective of this work is to determine if the reaction is of the exothermic or endothermic type, what is its activation energy, also to determine the half life of the enzyme invertase and the yield as a function of the volumetric flow rate of a fixed bed reactor. To obtain this data the amount of glucose and fructose formed is measured by the DNS method.

\section{Materials and Methods}

Experiments performed in this work used invertase enzyme of $44.35 \%$ humidity and $5 \%$ $\mathrm{w} / \mathrm{v}$ sucrose solution at $\mathrm{pH}$ 4.5. The spectrophotometer FEMTO 57965 was used to determine the concentrations of glucose and fructose at a wavelength of $540 \mathrm{~nm}$, whose methodology is already well described in Potrich and Amaral (2017). The LambeertBeer equation used is described in Equation 1:

$\mathrm{A}=0.4311 * \mathrm{~B} * \mathrm{C}(1)$

Wherein: " $A$ " is the absorbance; " $B$ " is the distance from the optical path, in these experiments the value is $1 \mathrm{~cm}$; " $\mathrm{C}$ " is the concentration of analyte, units in $\mathrm{mg} \mathrm{mL}^{-1}$.

The most widely used colorimetric method for the determination of reducing sugars uses 3,5dinitrosalicylic acid (DNS) as oxidizing agent. Also called the DNSA method, it oxidizes the functional groups of sugar and oxidizes the DNS to 3-amino-5-nitrosalicylic acid that absorbs light at $540 \mathrm{~nm}$ wavelength (Gandhi $e t$ al., 2017; Santos et al., 2017).

\section{Determination of activation energy}

Activation energy is the energy required for a given reaction to occur. The Arrhenius equation relates the activation energy and rate 
at which the reaction develops. Linearizing the Arrhenius equation by the Neperian logarithm application method, the activation energy is determined by the value of the angular coefficient divided by the universal gas constant, as shown in Equation 2 (Potrich and Amaral, 2017):

$\ln \mathrm{k}=\ln \mathrm{A}-\mathrm{E}_{\mathrm{a}} /(\mathrm{R} * \mathrm{~T})(2)$

To perform this experiment, a batch reactor was used in a thermal bath to maintain the temperature at $50{ }^{\circ} \mathrm{C}$ and $60{ }^{\circ} \mathrm{C} .1 \mathrm{ml}$ of $1 \mathrm{mg} /$ $\mathrm{ml}$ immobilized invertase enzyme solution was used, and $50 \mathrm{ml}$ sucrose solution was used. The protein content of the soluble enzyme was $185 \mathrm{mg}$ protein/g enzyme.

During determined intervals $(0,3,6,9,12$ and $21 \mathrm{~min}) 1 \mathrm{ml}$ of sample was withdrawn and added to a tube containing $4 \mathrm{ml}$ of distilled water. The tubes were placed in a $100{ }^{\circ} \mathrm{C}$ bath for 10 minutes to inactivate the enzyme. $1 \mathrm{ml}$ of this solution was collected and diluted with a further $9 \mathrm{ml}$ of distilled water, totaling a 1/50 dilution. With this dilution it is possible to determine the amount of fructose and glucose produced by the spectrophotometer reading using the DNS method. The equations used in this experiment are described in Equations 3, 4 and 5.

$\mu$ moles of glucose $=\left(C . V_{r}\right) /(M W)(3)$

$\mathrm{A}=\left(\mathrm{b}^{*} \mu\right.$ moles of glucose $) /(\mathrm{ml}$ of enzyme solution used) (4)

$\mathrm{A}_{\mathrm{e}}=($ A. $\mu$ moles of glucose $) /(\mathrm{mg}$ of protein used) (5)

wherein: "C" is the amount of glucose more fructose formed $(\mathrm{mg} / \mathrm{ml})$; "Vr" is the reaction volume in the considered time; "MW" is the molecular weight of glucose more fructose; "A" is the enzyme activity; "Ae" is the specific activity of the enzyme; "a" is the linear coefficient of the adjusted line; and " $b$ " is the slope of the adjusted line.

\section{Determination of half-life}

Denaturation of the enzyme by the effect of temperature is obtained by incubating the enzyme in water for a certain period of time and then determining the residual activity.

The relationship between initial and residual activity at a given time is of the exponential type, as can be seen in Equation 6:

$\mathrm{A}_{\text {in }}=\mathrm{A}_{\text {in }}{ }^{0} \mathrm{e}^{-\mathrm{kd} * \mathrm{t}}(6)$

wherein: " $\mathrm{A}_{\text {in }}$ " is the residual enzymatic activity observed in the reactor after a certain incubation period (30, 60 and 90 minutes), units in $\mathrm{U} / \mathrm{ml}$; " $\mathrm{A}_{\mathrm{in}}{ }^{0}$ " is the initial enzymatic activity in the reactor without enzyme incubation, units in $\mathrm{U} / \mathrm{ml}$; " $\mathrm{k}_{\mathrm{d}}$ " is the constant of denaturation of the enzyme a given temperature, units in $\mathrm{min}^{-1}$; and " $\mathrm{t}$ " is the reaction time, units in min.

The unit of enzymatic activity (U) corresponds to the amount of enzyme that catalyzes the transformation of one micromole of glucose and fructose per minute under the conditions of the experiment.

Applying logarithm in Equation 6 and plotting its graph, the value of the constant $k_{d}$ is found by the slope of the line. Equation 7 illustrates the linearized function:

$\ln \left(\mathrm{A}_{\mathrm{in}} / \mathrm{A}_{\mathrm{in}}{ }^{0}\right)=-\mathrm{k}_{\mathrm{d}} * \mathrm{t}(7)$

The half-life time is the stability criterion most used in the experiments. It occurs when the enzymatic activity decays exactly metadata from the initial activity, with the ratio $\mathrm{A}_{\text {in }} / \mathrm{A}_{\text {in }}{ }^{0}$ equal to 0.5. Thus, Equation 8 is obtained:

$\mathrm{t}_{1 / 2}=(\ln 0.5) /\left(-\mathrm{k}_{\mathrm{d}}\right)(8)$ 
To perform this experiment, a batch reactor was used in a thermal bath to maintain the temperature at $55{ }^{\circ} \mathrm{C}$. A solution with $0.5 \mathrm{ml}$ of enzyme at a concentration of $0.1 \mathrm{~g} / \mathrm{L}$ and $9.5 \mathrm{ml}$ of sucrose solution was used for this experiment. The determination of glucose and fructose content was performed using the DNS method.

\section{Determination of the yield in a fixed bed reactor}

In this experiment, the yield of the enzyme invertase was determined as a function of the flow rate in a fixed bed reactor. For this, the residence time of the fluid in the reactor was maintained constant, by means of the change of mass of the catalyst and flow of the fluid.

A fixed bed reactor with internal diameter of $0.75 \mathrm{~cm}$ and $40 \mathrm{~cm}$ of useful height (Figure 1) was used in a thermostated bath at $45^{\circ} \mathrm{C}$.

In the reactor is added $1.5 \mathrm{~g}$ of immobilized invertase enzyme and adjusted to flow rate to $3.1 \mathrm{ml} / \mathrm{min}$. A $0.5 \mathrm{ml}$ sample is withdrawn at 10 min intervals for 30 minutes.

This sample is added in a tube containing 9.5 $\mathrm{ml}$ of distilled water (1:20 dilution) and taken to the boiling bath for 10 minutes to deactivate the enzyme.

The sample is then diluted again in the ratio of 1:3, totaling a dilution of 1:60. The amount of glucose and fructose formed is determined by the DNS method. After completing a cycle, add another $1.5 \mathrm{~g}$ of enzyme and change the flow rate to $6.2 \mathrm{ml} / \mathrm{min}$ and then to 9.3 $\mathrm{ml} / \mathrm{min}$. The yield formula $X_{a}$ is given by Equation 9, this factor of 0.95 is because sucrose has $95 \%$ of the molecular mass of the glucose sum with fructose.

$\mathrm{X}_{\mathrm{A}}(\%)=0.95 * 100 *$ (concentration of glucose + fructose)/(concentration of sucrose) (9)

\section{Results and Discussion}

\section{Determination of activation energy}

Table 1 shows the data obtained for the temperature of $50{ }^{\circ} \mathrm{C}$, while in Table 2 the data for the temperature of $60{ }^{\circ} \mathrm{C}$ are found. In the graph of Figure 1 these data are plotted together with the adjusted curve.

From the graph of Figure 1, it can be observed that the increase in temperature decreases the amount of glucose formed, so the reaction is exothermic. With the slope obtained from the lines of Figure 1 together with Equations 4 and 5, Table 3 is obtained. With the data in Table 3 the graph of Figure 2 is plotted.

By the slope of the line found in Figure 2 is obtained the value of the Activation Energy divided by the universal constant of the gases, so the value of the activation energy for the conversion reaction of sucrose in glucose plus fructose is $25.0723 \mathrm{~kJ}$. This found value of activation energy is in agreement with the values found in the dissertation of Santos (2010) and in the dissertation of Silva (2010).

\section{Determination of half-life}

In Tables 4 to 7 are the data obtained for the time of $0,30,60$ and 90 minutes of incubation respectively. In Figure 3 is the graph with the data of these 4 tables together with the respective adjustment lines.

With the slopes of the straight lines obtained in Figure 3, Table 8 is assembled. With the data in Table 8 the graph of Figure 4 was obtained.

By the slope of the line obtained in Figure 4 the value of the denaturing constant of the enzyme $\mathrm{k}_{\mathrm{d}}$ is $0.0106 \mathrm{~min}^{-1}$. Multiplying the inverse of this value by $\ln 0.5$ the half-life of the enzyme of $65.3912 \mathrm{~min}$ is found. 
Fig.1 Graph of the amount of glucose formed in function of time for temperatures of $50^{\circ} \mathrm{C}$ and $60^{\circ} \mathrm{C}$

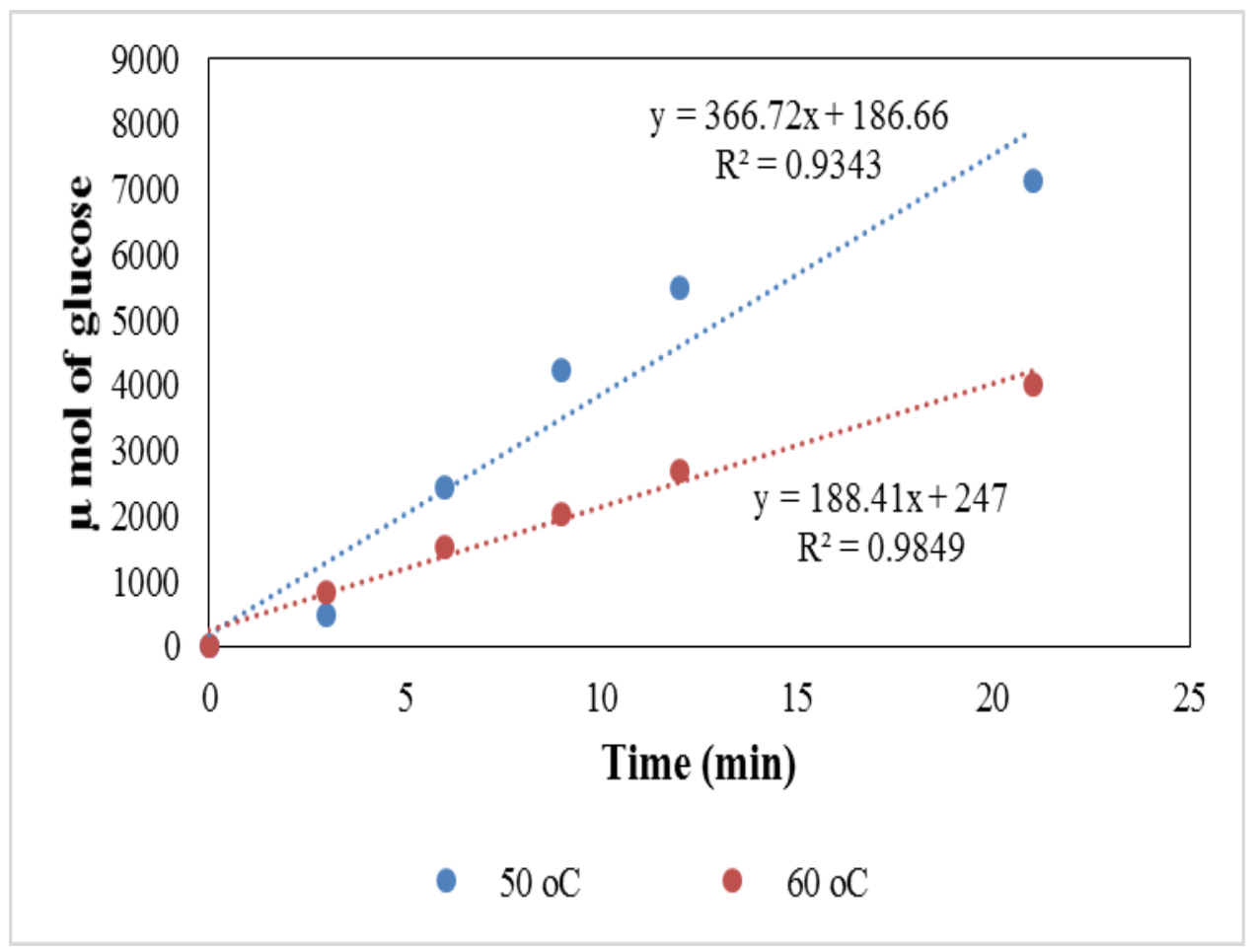

Fig.2 Relationship between the logarithm of the specific activity of the enzyme and the inverse of the time

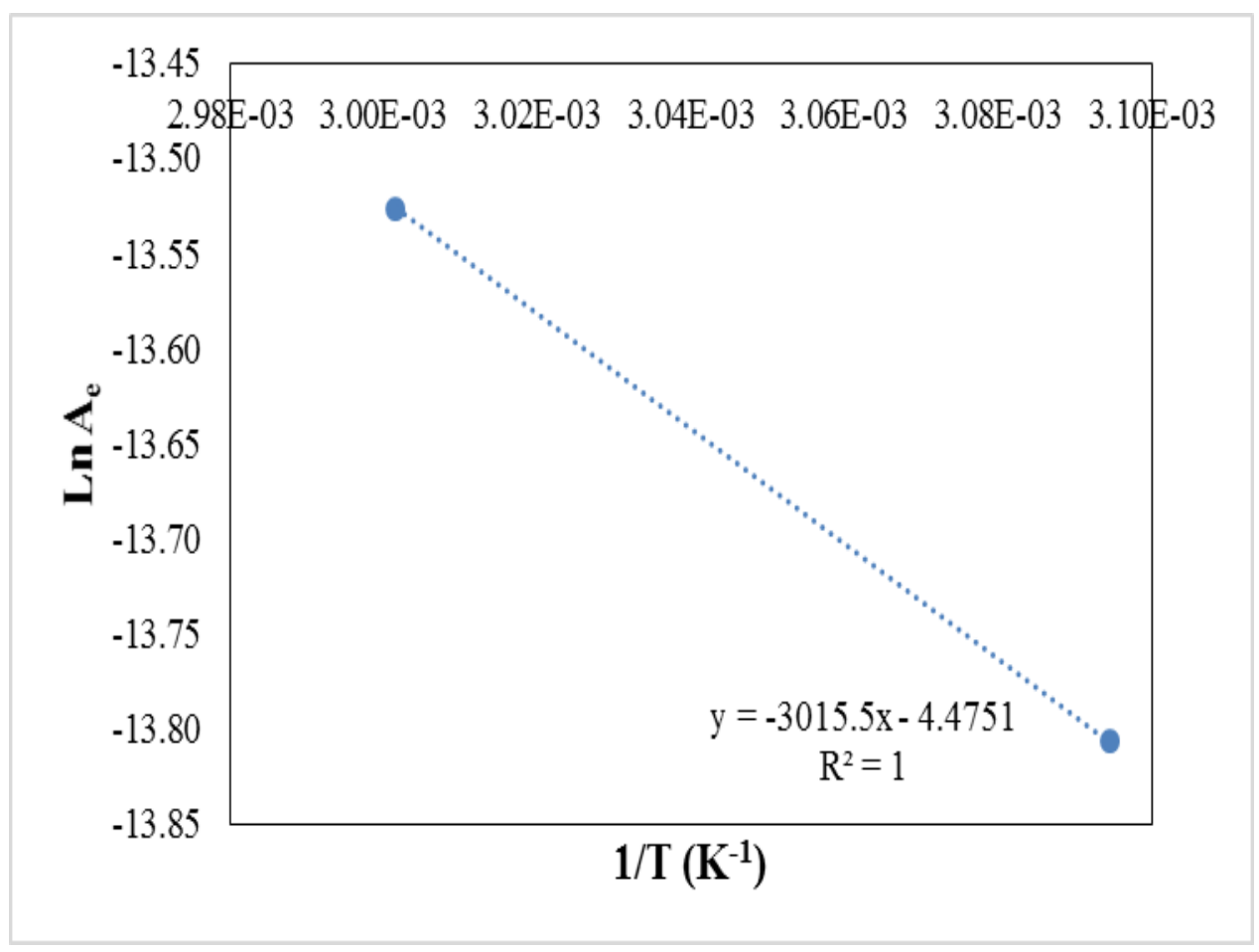


Fig.3 Graph of the amount of glucose formed in function of time for four different incubation time values

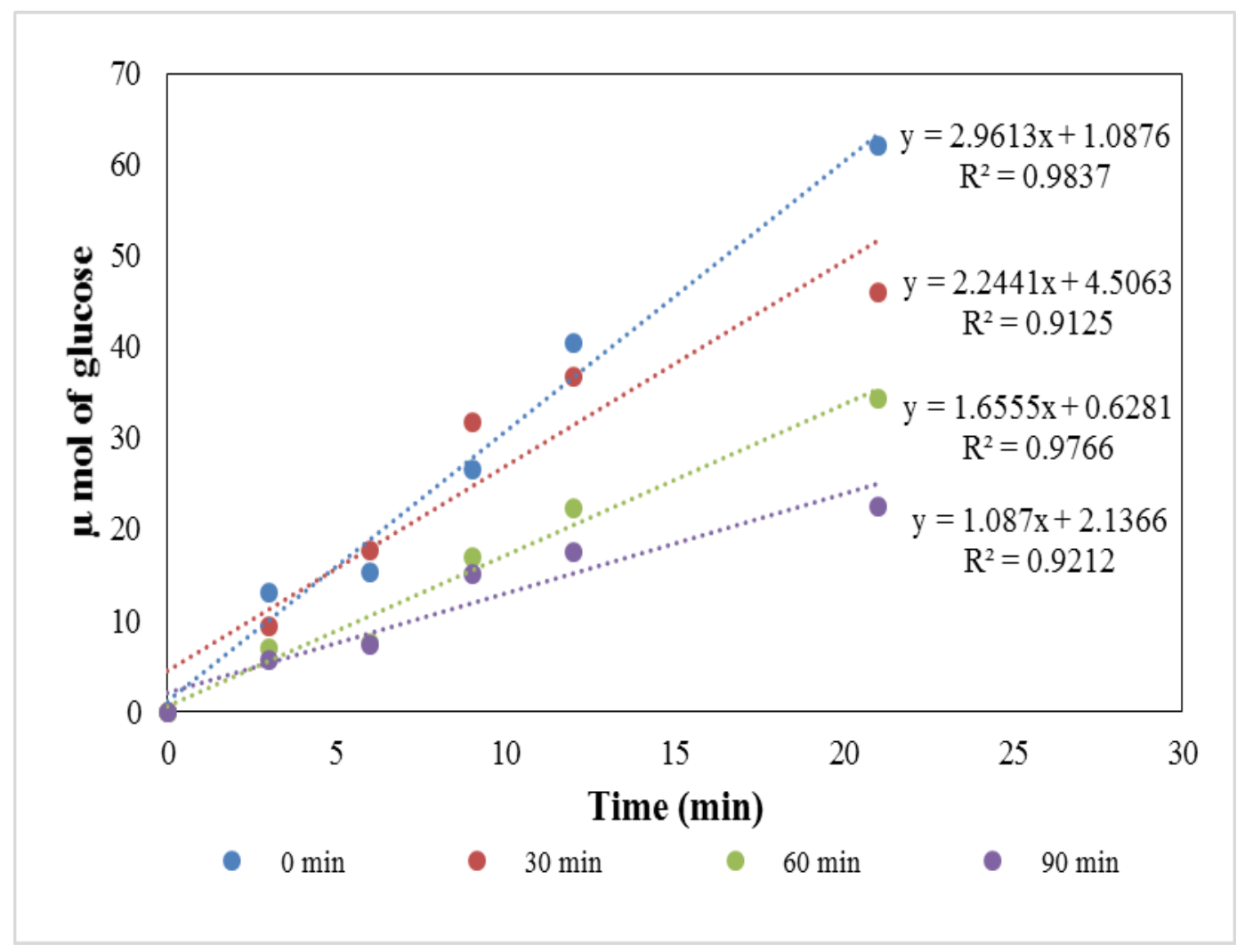

Fig.4 Relationship between the logarithm of residual enzymatic activity and the incubation time

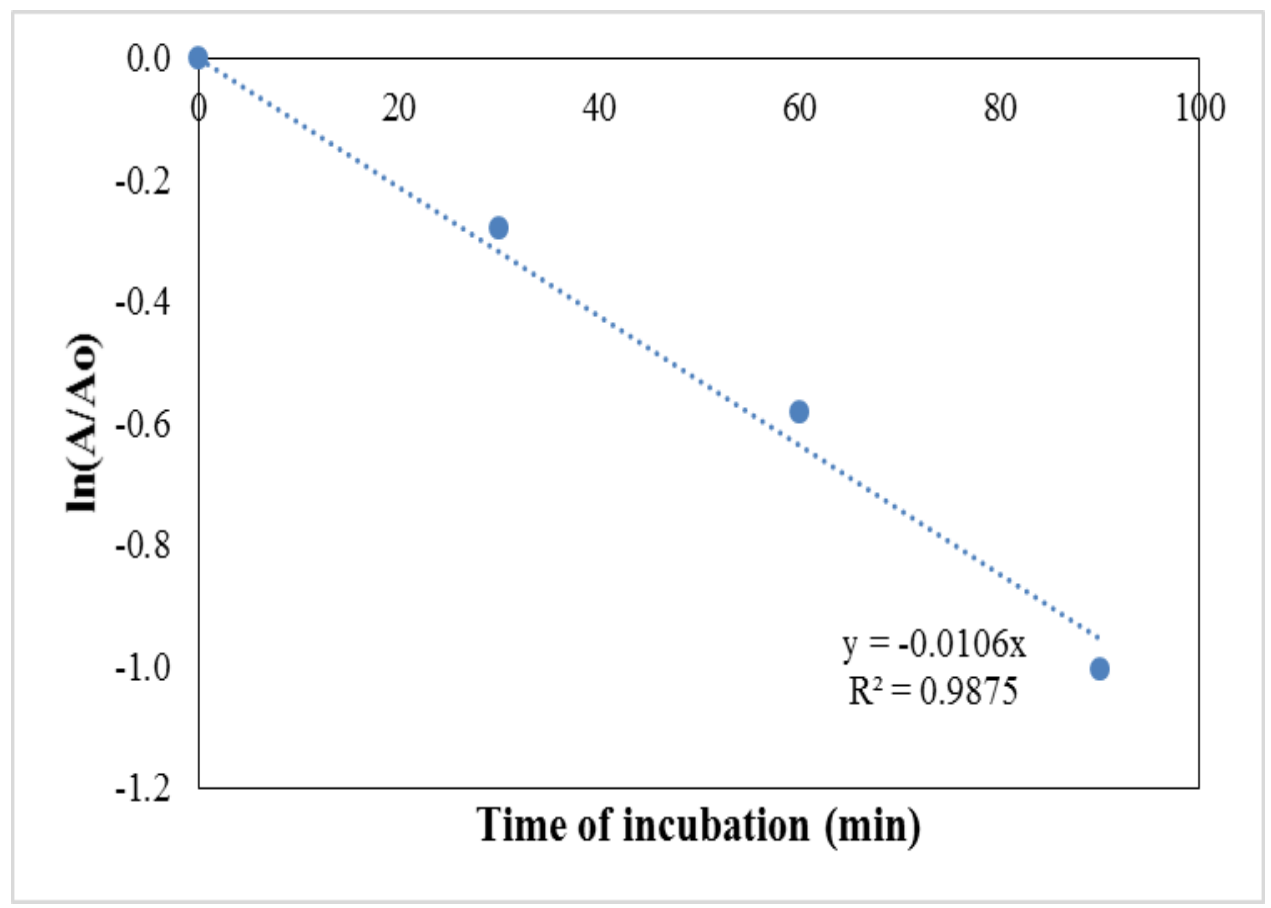


Fig.5 Conversion rate as a function of volumetric flow

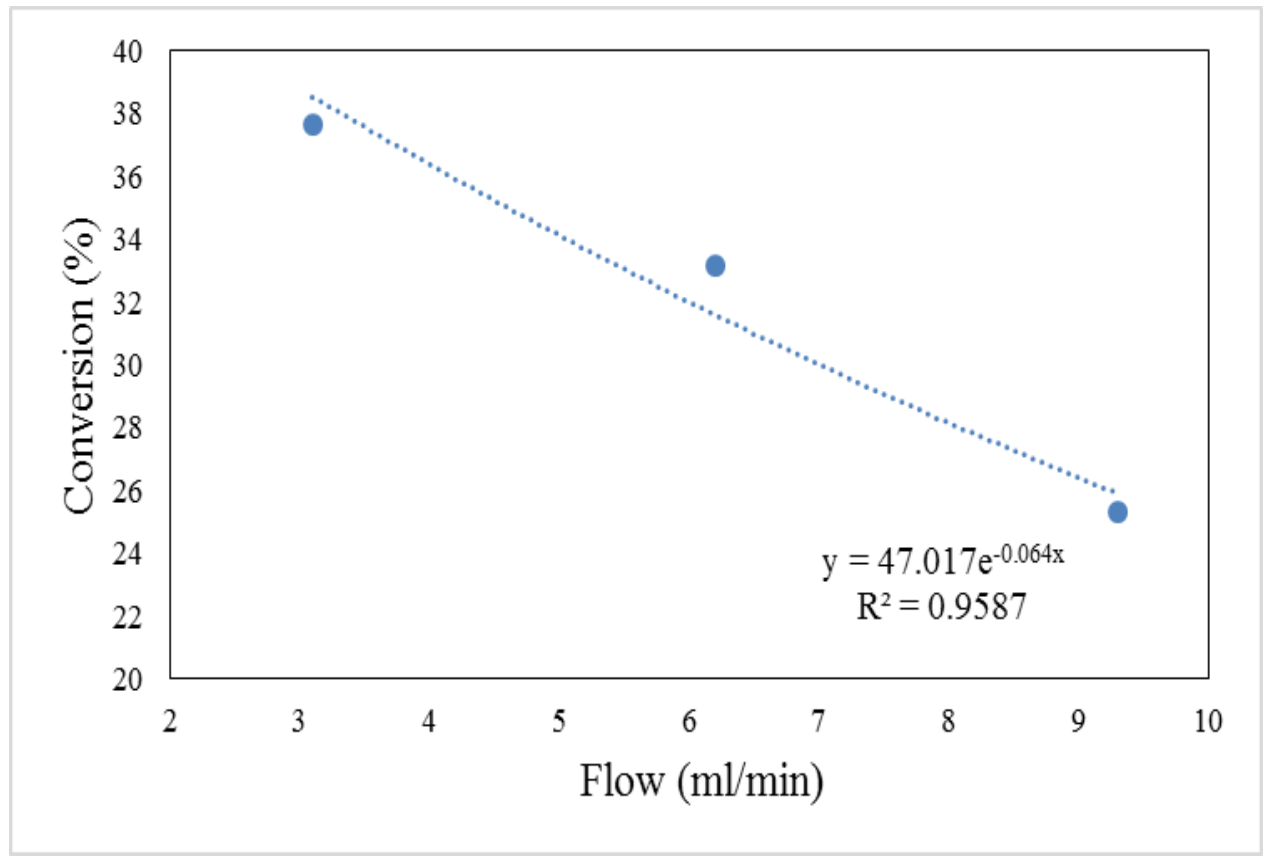

Table.1 Absorbance data, and their respective concentrations, the reaction volume and amount of moles of glucose formed at the temperature of $50{ }^{\circ} \mathrm{C}$

\begin{tabular}{|c|c|c|c|c|c|c|}
\hline $\begin{array}{c}\text { Time } \\
(\mathbf{m i n})\end{array}$ & Absorbance & $\begin{array}{c}\text { Concentration } \\
(\mathbf{m g} / \mathbf{m l})\end{array}$ & $\begin{array}{c}\text { Actual } \\
\text { concentration } \\
(\mathbf{m g} / \mathbf{m l})\end{array}$ & $\begin{array}{c}\text { Formed } \\
\text { concentration } \\
(\mathbf{m g} / \mathbf{m l})\end{array}$ & $\mathbf{V}_{\mathbf{r}}(\mathbf{m l})$ & $\begin{array}{c}\boldsymbol{\mu} \text { moles of } \\
\text { glucose }\end{array}$ \\
\hline $\mathbf{0}$ & 0.031 & 0.0719 & 3.5955 & 0.0000 & 51 & 0.0000 \\
\hline $\mathbf{3}$ & 0.062 & 0.1438 & 7.1909 & 3.5955 & 50 & 498.9363 \\
\hline $\mathbf{6}$ & 0.186 & 0.4315 & 21.5727 & 17.9773 & 49 & $2,444.7884$ \\
\hline $\mathbf{9}$ & 0.305 & 0.7075 & 35.3746 & 31.7792 & 48 & $4,233.5559$ \\
\hline $\mathbf{1 2}$ & 0.395 & 0.9163 & 45.8130 & 42.2176 & 47 & $5,506.9703$ \\
\hline $\mathbf{2 1}$ & 0.535 & 1.2410 & 62.0506 & 58.4551 & 44 & 7138.3314 \\
\hline
\end{tabular}

Table.2 Absorbance data, and their respective concentrations, the reaction volume and amount of moles of glucose formed at the temperature of $60{ }^{\circ} \mathrm{C}$

\begin{tabular}{|c|c|c|c|c|c|c|}
\hline $\begin{array}{c}\text { Time } \\
(\mathbf{m i n})\end{array}$ & Absorbance & $\begin{array}{c}\text { Concentration } \\
(\mathbf{m g} / \mathbf{m l})\end{array}$ & $\begin{array}{c}\text { Actual } \\
\text { concentration } \\
(\mathbf{m g} / \mathbf{m l})\end{array}$ & $\begin{array}{c}\text { Formed } \\
\text { concentration } \\
(\mathbf{m g} / \mathbf{m l})\end{array}$ & $\mathbf{V}_{\mathbf{r}}(\mathbf{m l})$ & $\begin{array}{c}\boldsymbol{\mu} \text { moles of } \\
\text { glucose }\end{array}$ \\
\hline $\mathbf{0}$ & 0.025 & 0.0580 & 2.8996 & 0.0000 & 51 & 0.0000 \\
\hline $\mathbf{3}$ & 0.077 & 8.9306 & 8.9306 & 6.0311 & 50 & 836.9256 \\
\hline $\mathbf{6}$ & 0.121 & 14.0339 & 14.0339 & 11.1343 & 49 & $1,514.1915$ \\
\hline $\mathbf{9}$ & 0.157 & 18.2092 & 18.2092 & 15.3097 & 48 & $2,039.5233$ \\
\hline $\mathbf{1 2}$ & 0.202 & 23.4284 & 23.4284 & 20.5289 & 47 & $2,677.8400$ \\
\hline $\mathbf{2 1}$ & 0.309 & 0.7168 & 35.8386 & 32.9390 & 44 & 4022.3931 \\
\hline
\end{tabular}


Table.3 Enzymatic activity in function of temperature

\begin{tabular}{|c|c|c|c|c|}
\hline $\begin{array}{c}\text { Temperature } \\
\left(\mathbf{(}^{\mathbf{C}} \mathbf{C}\right)\end{array}$ & $\begin{array}{c}\mathbf{A} \\
(\mathbf{m o l} / \mathbf{m i n} . \mathbf{m l})\end{array}$ & $\begin{array}{c}\mathbf{A}_{\mathbf{e}} \\
(\mathbf{m o l} / \mathbf{m i n} \cdot \mathbf{m g})\end{array}$ & $\mathbf{1 / T}\left(\mathbf{K}^{-\mathbf{1}}\right)$ & $\ln \mathbf{A}_{\mathbf{e}}$ \\
\hline $\mathbf{5 0}$ & $186.66 \times 10^{-6}$ & $1.0090 \times 10^{-6}$ & $3.0945 \times 10^{-3}$ & -13.8066 \\
\hline $\mathbf{6 0}$ & $247.00 \times 10^{-6}$ & $1.3351 \times 10^{-6}$ & $3.0017 \times 10^{-3}$ & -13.5265 \\
\hline
\end{tabular}

Table.4 Absorbance data, and their respective concentrations, the reaction volume and amount of moles of glucose formed without incubation

\begin{tabular}{|c|c|c|c|c|c|}
\hline $\begin{array}{c}\text { Time } \\
(\mathbf{m i n})\end{array}$ & Absorbance & $\begin{array}{c}\text { Concentration } \\
(\mathbf{m g} / \mathbf{m l})\end{array}$ & $\begin{array}{c}\text { Formed } \\
\text { concentration } \\
(\mathbf{m g} / \mathbf{m l})\end{array}$ & $\mathbf{V}_{\mathbf{r}}(\mathbf{m l})$ & $\begin{array}{c}\boldsymbol{\mu} \text { moles } \\
\text { of glucose }\end{array}$ \\
\hline $\mathbf{0}$ & 0.040 & 0.0928 & 0.0000 & 50.5 & 0.0000 \\
\hline $\mathbf{3}$ & 0.081 & 0.1879 & 0.0951 & 49.5 & 13.0657 \\
\hline $\mathbf{6}$ & 0.089 & 0.2064 & 0.1137 & 48.5 & 15.2996 \\
\hline $\mathbf{9}$ & 0.127 & 0.2946 & 0.2018 & 47.5 & 26.6046 \\
\hline $\mathbf{1 2}$ & 0.175 & 0.4059 & 0.3132 & 46.5 & 40.4138 \\
\hline $\mathbf{2 1}$ & 0.262 & 0.6077 & 0.5150 & 43.5 & 62.1707 \\
\hline
\end{tabular}

Table.5 Absorbance data, and their respective concentrations, the reaction volume and amount of moles of glucose formed after 30 minutes of incubation

\begin{tabular}{|c|c|c|c|c|c|}
\hline $\begin{array}{c}\text { Time } \\
(\mathbf{m i n})\end{array}$ & Absorbance & $\begin{array}{c}\text { Concentration } \\
(\mathbf{m g} / \mathbf{m l})\end{array}$ & $\begin{array}{c}\text { Formed } \\
\text { concentration } \\
(\mathbf{m g} / \mathbf{m l})\end{array}$ & $\mathbf{V}_{\mathbf{r}}(\mathbf{m l})$ & $\begin{array}{c}\boldsymbol{\mu} \text { moles } \\
\text { of glucose }\end{array}$ \\
\hline $\mathbf{0}$ & 0.070 & 0.1624 & 0.0000 & 42.5 & 0.0000 \\
\hline $\mathbf{3}$ & 0.105 & 0.2436 & 0.0812 & 41.5 & 9.3510 \\
\hline $\mathbf{6}$ & 0.138 & 0.3201 & 0.1577 & 40.5 & 17.7299 \\
\hline $\mathbf{9}$ & 0.195 & 0.4523 & 0.2900 & 39.5 & 31.7871 \\
\hline $\mathbf{1 2}$ & 0.218 & 0.5057 & 0.3433 & 38.5 & 36.6831 \\
\hline $\mathbf{2 1}$ & 0.271 & 0.6286 & 0.4662 & 35.5 & 45.9376 \\
\hline
\end{tabular}

Table.6 Absorbance data, and their respective concentrations, the reaction volume and amount of moles of glucose formed after 60 minutes of incubation

\begin{tabular}{|c|c|c|c|c|c|}
\hline $\begin{array}{c}\text { Time } \\
(\mathbf{m i n})\end{array}$ & Absorbance & $\begin{array}{c}\text { Concentration } \\
(\mathbf{m g} / \mathbf{m l})\end{array}$ & $\begin{array}{c}\text { Formed concentration } \\
(\mathbf{m g} / \mathbf{m l})\end{array}$ & $\mathbf{V}_{\mathbf{r}}(\mathbf{m l})$ & $\begin{array}{c}\boldsymbol{\mu} \text { moles } \\
\text { of glucose }\end{array}$ \\
\hline $\mathbf{0}$ & 0.133 & 0.3085 & 0.0000 & 34.5 & 0.0000 \\
\hline $\mathbf{3}$ & 0.165 & 0.3827 & 0.0742 & 33.5 & 6.9014 \\
\hline $\mathbf{6}$ & 0.169 & 0.3920 & 0.0835 & 32.5 & 7.5323 \\
\hline $\mathbf{9}$ & 0.217 & 0.5034 & 0.1949 & 31.5 & 17.0347 \\
\hline $\mathbf{1 2}$ & 0.247 & 0.5730 & 0.2644 & 30.5 & 22.3845 \\
\hline $\mathbf{2 1}$ & 0.327 & 0.7585 & 0.4500 & 27.5 & 34.3461 \\
\hline
\end{tabular}


Table.7 Absorbance data, and their respective concentrations, the reaction volume and amount of moles of glucose formed after 90 minutes of incubation

\begin{tabular}{|c|c|c|c|c|c|}
\hline $\begin{array}{c}\text { Time } \\
(\mathbf{m i n})\end{array}$ & Absorbance & $\begin{array}{c}\text { Concentration } \\
(\mathbf{m g} / \mathbf{m l})\end{array}$ & $\begin{array}{c}\text { Formed concentration } \\
(\mathbf{m g} / \mathbf{m l})\end{array}$ & $\mathbf{V}_{\mathbf{r}}(\mathbf{m l})$ & $\begin{array}{c}\boldsymbol{\mu} \text { moles of } \\
\text { glucose }\end{array}$ \\
\hline $\mathbf{0}$ & 0.152 & 0.3526 & 0.0000 & 26.5 & 0.0000 \\
\hline $\mathbf{3}$ & 0.187 & 0.4338 & 0.0812 & 25.5 & 5.7458 \\
\hline $\mathbf{6}$ & 0.198 & 0.4593 & 0.1067 & 24.5 & 7.2555 \\
\hline $\mathbf{9}$ & 0.252 & 0.5846 & 0.2320 & 23.5 & 15.1290 \\
\hline $\mathbf{1 2}$ & 0.273 & 0.6333 & 0.2807 & 22.5 & 17.5272 \\
\hline $\mathbf{2 1}$ & 0.332 & 0.7701 & 0.4175 & 19.5 & 22.5970 \\
\hline
\end{tabular}

Table.8 Residual enzymatic activity for each incubation time

\begin{tabular}{|c|c|c|c|c|}
\hline $\begin{array}{c}\text { Time of incubation } \\
(\text { min) }\end{array}$ & $\mathbf{0}$ & $\mathbf{3 0}$ & $\mathbf{6 0}$ & $\mathbf{9 0}$ \\
\hline $\begin{array}{c}\mathbf{A}_{\text {in }}(\boldsymbol{\mu} \text { moles of } \\
\text { glucose/min.ml })\end{array}$ & 2.9613 & 2.2441 & 1.6555 & 1.0870 \\
\hline $\mathbf{L n}\left(\mathbf{A}_{\text {in }} / \mathbf{A}_{\text {in }}\right)$ & 0.0000 & -0.2773 & -0.5815 & -1.002 \\
\hline
\end{tabular}

Table.9 Yield of sucrose conversion reaction to three different flows in a fixed bed reactor

\begin{tabular}{|c|c|c|c|c|c|}
\hline $\begin{array}{c}\text { Flow } \\
(\mathrm{ml} / \mathrm{min})\end{array}$ & Absorbance & $\begin{array}{c}\text { Concentration } \\
(\mathrm{mg} / \mathrm{ml})\end{array}$ & $\begin{array}{c}\text { Actual } \\
\text { concentration } \\
(\mathbf{m g} / \mathbf{m l})\end{array}$ & $\begin{array}{c}\text { Average } \\
\text { concentration } \\
(\mathrm{g} / \mathrm{ml})\end{array}$ & $\begin{array}{c}\text { Conversion } \\
(\%)\end{array}$ \\
\hline \multirow[t]{3}{*}{3.1} & 0.143 & 0.3317 & 19.9026 & \multirow[t]{3}{*}{0.0198} & \multirow[t]{3}{*}{37,6386} \\
\hline & 0.141 & 0.3271 & 19.6242 & & \\
\hline & 0.143 & 0.3317 & 19.9026 & & \\
\hline \multirow[t]{3}{*}{6.2} & 0.126 & 0.2923 & 17.5365 & \multirow[t]{3}{*}{0.0174} & \multirow[t]{3}{*}{33,1431} \\
\hline & 0.126 & 0.2923 & 17.5365 & & \\
\hline & 0.124 & 0.2876 & 17.2582 & & \\
\hline \multirow[t]{3}{*}{9.3} & 0.097 & 02250 & 13.5003 & \multirow[t]{3}{*}{0.0133} & \multirow[t]{3}{*}{25,2981} \\
\hline & 0.098 & 0.2273 & 13.6395 & & \\
\hline & 0.092 & 0.2134 & 12.8045 & & \\
\hline
\end{tabular}

This found value of half-life time is consistent with the values found in the dissertation of Giraldo (2011).

Determination of the yield in a fixed bed reactor

The data obtained in this experiment are shown in Table 9. The mean concentration between the three times $(10,20$ and 30 minutes) was calculated and its conversion calculated by Equation 9. Subsequently with the data of Table 9, the graph of Figure 5 was plotted.

The function obtained in the graph of Figure 5 is of the exponential type because only in the infinite flow a zero conversion rate is obtained, in addition to never reaching a negative yield. For the flow equal to zero the 
maximum conversion is obtained, which is $47.017 \%$. This yield value corresponds to the found value of Saccharomyces cerevisiae strain LCM001 from the dissertation of Parazzi Junior (2006).

In the adjustments of the curves the lowest $\mathrm{R}^{2}$ value was 0.9125 , showing the good reliability of the results found here. In addition, the results found were compared to the literature showing values very close to each other. The results showed that the reaction of hydrolysis of the sucrose to the production of invert sugar is exothermic with activation energy $25.0723 \mathrm{~kJ}$, showing that the reaction is more suitable at lower temperatures consuming less energy and decreasing the probability of degradation of the enzyme. It is not suitable to incubate the enzyme for a long time since its half-life is only $65.3912 \mathrm{~min}$, showing that the enzyme has a rapid degradation. The maximum conversion obtained was $47.017 \%$, this yield is low, indicating that the reactor must have a well-designed recycling system to obtain a conversion close to $100 \%$. With the data obtained in this research it is possible to design a hydrolysis reaction system with the best operating conditions to obtain the best yield with the lowest cost.

\section{References}

Atkins, P. W., 2006. Physical Chemistry. $8^{\text {th }}$ Ed. New York: Freeman.

Baraldi, I. J., Giordano, R. L. C., Zangirolani, T. C., 2016. Enzymatic hydrolysis as an environmentally friendly process compared to thermal hydrolysis for instant coffee production. Brazilian Journal of Chemical Engineering, 33(4): 763-771.

Cantu, Y., Remes, A., Reyna, A., Martinez, D., Villareal, J., Ramos, H., Trevino, S., Tamez, C., Martinez, A., Eubanls, T., Parsons, J. G., 2014. Thermodynamics, kinetics, and activation energy studies of the sorption of chromium (III) and $\begin{array}{lllll}\text { chromium (VI) to } & \mathrm{Mn}_{3} \mathrm{O}_{4}\end{array}$ nanomaterial. Chemical Engineering Journal, 254(15): 374-383.

Gandhi, Y. S., Bankar, V. H., Vishwakarma, R. P., Satpute, S. R., Upkare, M. M., 2017. Reducing Sugar Determination of Jaggery by Classical Lane and Eynon Method \& 3,5-Dinitrosalicylic Acid Method. Imperial Journal of Interdisciplinary Research, 3(6): 602606.

Giraldo, M. A., 2011. Purificação e Caracterização Bioquímica da Invertase Extracelular Produzida pelo Fungo Filamentoso Aspergillus terraus. Dissertation of the Graduate Program in Biotechnology of the Institute of Chemistry, UNESP, Araraquara-SP, Brazil, 106 p.

Homaei, A. A., Sariri, R., Vianello, F., Stevanato, R., 2013. Enzyme immobilization: an update. Journal of Chemical Biology, 6(4): 185-205.

Margetić, A., Vujčić, Z., 2017. Comparative study of stability of soluble and cell wall invertase from Saccharomyces cerevisiae. Preparative Biochemistry and Biotechnology, 47(3): 305-311.

Parazzi Junior, O., 2006. Metabolização de açucares em linhagens de Saccharomyces cerevisiae com e sem transportador de sacarose e diferentes atividades de invertase. Dissertation of the "Luiz de Queiroz" School of Agriculture, USP, Piracicaba-SP, Brazil, 106 p.

Potrich, E., Amaral, L. S., 2017. Determination of kinetic parameters of the crystal violet reaction with sodium hydroxide applying absorbance technique and the laws of LambeertBeer and Arrhenius. Enciclopédia Biosfera, Centro Científico Conhecer, 14(25): 1852-1861. 
Santos, A. A., Deoti, J. R., Müller, G., Dário, M. G., Stambuk, B. U., Junior, S. L. A., 2017. Microwell plate-based method for the determination of reducing sugars with the DNS reagent. Brazilian Journal of Food Technology, 20: 1-9.

Santos, A. F., 2010. Imobilização de invertase comercial e de Saccharomyces cerevisiae em sabugo de milho e bagaço de cana-de-açúcar. Dissertation of the Post-Graduate Program in Food and Nutrition, UNESP, Araraquara-SP, Brazil, 92 p.

Silva, A. R., 2010. Conversão Multienzimática da Sacarose em Frutose e Ácido Glicônico usando
Reatores Descontínuo e Contínuo. Dissertation of the Post-Graduate Program in BiochemicalPharmaceutical Technology, USP, São Paulo-SP, Brazil, 75 p.

Yamane, T., Sirirote, P., Shimizu, S., 1987. Evaluation of half-life of immobilized enzyme during continuous reaction in bioreactors: A theoretical study. Biotechnology and Bioengineering, 30(8): 963-969.

Zamora, M. C., Buratti, F. M., Otero-Losada, M. E., 1997. Temporal study of sucrose and fructose relative sweetness. Journal of Sensory Studies, 13: 213-228.

\section{How to cite this article:}

Erich Potrich and Larissa Souza Amaral. 2018. Activation Energy, Half-Life and Yield of the Hydrolysis Reaction of Sucrose Catalyzed by the Enzyme Invertase Produced by Yeast Saccharomyces cerevisiae. Int.J.Curr.Microbiol.App.Sci. 7(02): 806-816. doi: https://doi.org/10.20546/ijcmas.2018.702.102 